\title{
PENGEMBANGAN PROFESI BERKELANJUTAN GURU SMA NEGERI KOTA KENDARI
}

\author{
Rahmawati M., Nurzaima, Nasir \\ Universitas Muhammadiyah Kendari \\ Rahma.wati937@yahoo.com
}

\begin{abstract}
ABSTRAK
Perkembangan teknologi membawa perubahan ke semua lini orang; perilaku manusia, cara hidup, transportasi, kebiasaan hingga cara belajar juga dipengaruhi oleh perkembangan ini. Dalam fase sebelumnya, pendidikan adalah proses satu arah, di mana guru menjadi satusatunya sumber informasi atau pengetahuan bagi siswa. Lebih dari itu, siswa lebih dulu mengetahui informasi yang terjadi di belahan otak lain dibandingkan dengan guru. Ini bisa terjadi jika para guru tidak dapat beradaptasi dengan perkembangan teknologi. Konsep pengembangan profesional berkelanjutan adalah sistem yang akan menciptakan budaya baru sehingga guru dapat mewaspadai perubahan yang terjadi. Penelitian ini mengeksplorasi implementasi pengembangan profesional berkelanjutan di sekolah menengah di seluruh Kota Kendari. Untuk mendapatkan data yang dimaksud, peneliti menggunakan pendekatan bola salju melalui wawancara, observasi, dan analisis data. Selanjutnya, data yang dikumpulkan dianalisis menggunakan model interaktif yang meliputi: reduksi data, penyajian data, dan penarikan kesimpulan dan verifikasi. Hasil dari penelitian ini adalah: 1) guru memiliki kesadaran untuk beradaptasi dengan situasi, terutama mengetahui dan menerapkan metode pengajaran terkini, tentu saja melalui pengembangan profesionalisme berkelanjutan; 2) Untuk mencapai kualitas pendidikan, itu harus didukung oleh pengembangan kompetensi guru seperti PKB, karena akan meningkatkan kompetensi guru untuk mencapai standar kompetensi yang ditetapkan dalam undang-undang dan peraturan yang berlaku, memperbarui kompetensi guru untuk bertemu guru kebutuhan dalam pengembangan sains, teknologi dan seni untuk memfasilitasi proses pembelajaran siswa, meningkatkan komitmen guru dalam melaksanakan tugas dan fungsi utama mereka sebagai profesional, menumbuhkan rasa cinta dan kebanggaan sebagai orang dengan profesi guru, meningkatkan citra, martabat dan martabat profesi guru di masyarakat.
\end{abstract}

Kata kunci: Profesi guru, Pengembangan Profesional Berkelanjutan.

\section{ABSTRACT}

Technological developments convey a change to all lines of people; human behavior, ways of life, transportation, habits to the way of learning is also influenced by these developments. In previous phases, education was a one-way process, where the teacher became the only source of information or knowledge for students. More than that, students first know information that occurs in other hemispheres compared to the teacher. This can happen if the teachers are unable to adapt to technological developments. The concept of sustainable professional development is a system that will create a new culture so that teachers can be aware of the changes that occur. This research explores the implementation of sustainable professional development in high schools throughout Kendari City. To obtain the data in question, the researcher used the snowball approach through interviewing, observation, and analysis data. Furthermore, the collected data is analyzed using an interactive model which includes: data reduction, data presentation, and drawing conclusions and verification. The results of this study are: 1) the teachers have an awareness to adapt to the situation, especially knowing and applying up-todate teaching methods, of course through the development of continuous professionalism; 2) In order to achieve the quality of education, it must be supported by the development of teacher competencies such as PKB, because it will improve teacher competencies to achieve the competency standards set out in applicable laws and regulations, update teacher competencies to meet teacher needs in the development of science, technology and art to facilitate the 
learning process of students, increase the commitment of teachers in carrying out their main tasks and functions as professionals, foster a sense of love and pride as persons with teacher professions, enhance the image, dignity and dignity of the teaching profession in the community.

Keywords: Teacher profession, Continuous Professional Development.

\section{PENDAHULUAN}

Perkembangan ilmu pengetahuan, teknologi dan aspek kehidupan lainnya berdampak bagi perubahan dan perkembangan dalam setiap aspek kehidupan manusia (Hoyle dan Wallace, 2007). Aspek ekonomi, sosial, pengetahuan bahkan layanan pendidikan di sekolah mengarahkan pada keharusan para guru untuk berbenah diri , karena pendidikan akan menjadi obat yang menyembuhkan segala penyakit masyarakat yang semakin meningkat. Tugas tersebut tidak hanya menjadi tanggung jawab negara semata, sekolah pun khususnya para guru harus memiliki inisiatif atau kemandirian meningkatkan profesionalitas dan kemampuan mereka.

Pada era globalisasi, profesi guru bermakna strategis, karena menyandang atau mengemban tugas sejati bagi proses kemanusiaan, pemanusiaan, pencerdasan, pembudayaan, dan pembangun karakter bangsa. Esensi dan eksistensi makna strategis profesi guru diakui dalam realitas sejarah pendidikan di Indonesia. Pengakuan itu memiliki kekuatan formal tatkala tanggal 2 Desember 2004, Presiden Soesilo Bambang Yudhoyono mencanangkan guru sebagai profesi.
Satu tahun kemudian, lahir Undangundang (UU) No. 14 Tahun 2005 tentang Guru dan Dosen, sebagai dasar legal pengakuan atas profesi guru dengan segala dimensinya.

Menghadapi

gambaran suasana tersebut di atas, banyak Negara lain telah mengembangkan sebuah sistem yang di sebut "Continuing Professional Development" (CPD) atau Pengembangan Keprofesionalan secara Berkelanjutan (PKB) (Energy, et. all, 2013).

Tujuan umum PKB adalah untuk meningkatkan kualitas layanan pendidikan di sekolah/madrasah dalam rangka meningkatkan mutu pendidikan. Sedangkan tujuan khusus PKB adalah sebagai berikut: 1) Memfasilitasi guru untuk mencapai standar kompetensi profesi yang telah ditetapkan; 2) Mamfasilitasi guru untuk terus memutakhirkan kompetensi yang mereka miliki sekarang dengan apa yang menjadi tuntutan ke depan berkaitan dengan profesinya; 3) Memotivasi guru-guru untuk tetap memiliki komitmen melaksanakan tugas pokok dan fungsinya sebagai tenaga professional; sserta 4) Mengangkat citra, harkat, martabat profesi guru, rasa hormat dan kebanggaan kepada 
peyandang profesi guru. Tim peneliti sangat yakin bahwa perbaikan sistem pendidikan bisa diawali dengan menciptakan sebuah kultur pembelajar yang harus dimiliki oleh semua guru dan seluruh pihak-pihak yang peduli terhadap pendidikan (Setiasih: 2010).

Pada prinsipnya, PKB mencakup kegiatan perencanaan, pelaksanaan, evaluasi dan refleksi yang didesain untuk meningkatkan karakteristik pengetahuan, pemahaman, dan ketrampilan (Day dan Sachs, 2003). PKB merupakan pengembangan keprofesian berkelanjutan yang dilaksanakan sesuai dengan kebutuhan guru untuk mencapai standar kompetensi profesi dan/atau meningkatkan kompetensinya di atas standar kompetensi profesinya yang sekaligus berimplikasi kepada perolehan angka kredit untuk kenaikan pangkat/jabatan fungsional guru. Pengembangan keprofesian berkelanjutan diharapkan akan mempersempit gap antara pengetahuan, keterampilan, kompotensi sosial dan kepribadian yang dimiliki saat ini dengan tuntutan pada masa yang akan datang terkait dengannya (Panjaitan, 2005).

Guru, dosen, instruktur dan tenaga pendidik lainnya merupakan profesi dalam dunia pendidikan. Sebagai bagian dari profesi, guru, dosen ataupun yang lainnya dituntut untuk memiliki sikap profesionalitas. Sikap profesional tersebut diharapkan mampu berkontribusi dalam memenuhi tujuan pembangunan nasional; mewujudkan insan Indonesia yang bertaqwa kepada Tuhan yang Maha Esa, unggul dalam penguasaan ilmu pengetahuan dan teknologi, memiliki moral dan kepribadian yang matang (Makka, 2003). Konsekuensi dari tenaga pendidik sebagai profesi yaitu Pengembangan Keprofesian Berkelanjutan PKB. Oleh karena itu, pengembangan keprofesian berkelanjutan perlu dilaksanakan berdasarkan Peraturan Menteri Negara Pemberdayaan Aparatur Negara dan Reformasi Biroraksi Nomor 16 Tahun 2009 tentang jabatan fungsional guru dan angka kreditnya.

Selama menjalankan tugastugas profesional, guru dituntut melakukan profesionalisasi atau proses penumbuhan dan pengembangan profesinya (Pulungan, 2015). Diperlukan upaya yang terus-menerus agar guru tetap memiliki pengetahuan dan keterampilan yang sesuai dengan tuntutan kurikulum serta kemajuan IPTEK. Di sinilah esensi pembinaan dan pengembangan profesional guru. Kegiatan ini dapat dilakukan atas prakarsa institusi, seperti pendidikan dan pelatihan, workshop, magang, studi banding, dan lain-lain. Prakarsa ini menjadi penting, karena secara umum guru masih memiliki keterbatasan, baik finansial, jaringan, waktu, akses, dan sebagainya. 
Peraturan Pemerintah (PP) No. 74 Tahun 2008 membedakan antara pembinaan dan pengembangan kompetensi guru yang belum dan yang sudah berkualifikasi S-1 atau DIV. Pengembangan dan peningkatan kualifikasi akademik bagi guru yang belum memenuhi kualifikasi S-1 atau D-IV dilakukan melalui pendidikan tinggi program S-1 atau program D-IV pada perguruan tinggi yang menyelenggarakan program pendidikan tenaga kependidikan dan/atau program pendidikan nonkependidikan yang terakreditasi.

Berdasarkan narasi-narasi di atas, maka poin-poin yang akan dikaji dalam tulisan ini adalah: 1) Bagaimanakah persepsi guru mengenai konsep pengembangan profesi berkelanjutan?

Bagaimanakah konsep pengembangan profesi berkelanjutan sebagai jaminan mutu pendidikan? dan 3) Apakah masalah-masalah yang dihadapi oleh para guru dalam mengimplementasikan

pengembangan

profesi

berkelanjutan?

\section{METODE PENELITIAN}

Penelitian ini merupakan penelitian kualitatif yang bersifat deskriptif-analitis. Pada praktenya, tim peneliti menangkap gejala-gejala dan fakta-fakta di lapangan yang berhubungan dengan topik penelitian, kemudian melakukan analisa sehingga diperoleh kesimpulan dan rekomendasi. Data mengenai aspek-aspek yang dikaji dikumpulkan dari SMA Negeri lingkup kerja kantor Dinas Pendidikan Provinsi Sultra Kota Kendari.

Pemilihan informan atau responden dalam penelitian ini ditentukan oleh key informan, selanjutnya dilakukan pengembangan sumber informasi melalui teknik snowball. Untuk memperoleh data yang diperukan, peneliti menggunakan teknik: wawancara dan analisi dokumen. Selanjutnya, data yang terkumpul dengan teknik model interaktif. Aktivitas dalam analisis ini meliputi reduksi data (data reduction), penyajian data (data display), serta penarikan kesimpulan dan verifikasi (conclusion drawing/ verification).

Pada saat pengumpulan data, reduksi/pemfokusan dilakukan dengan membuat ringkasan dari catatan-catatan yang diperoleh di lapangan. Pembuatan ringkasan tersebut, juga disertai dengan membuat coding, memusatkan teman, menentukan batas-batas permasalahan dan menulis memo. Sejak awal pengumpulan data, peneliti telah memahami arti dari berbagai hal yang dipertanyakan, arahan sebab-akibat dan berbagai proposisi namun tetap terbuka dan bersikap skeptis. Konklusi-konklusi yang ada pada awalnya mungkin kurang jelas, kemudian semakin meningkat secara eksplisit. Sesudah pengumpulan data berakhir, peneliti selanjutnya bergerak pada tiga 
komponen analisis yaitu reduksi, penyajian serta akhirnya menarik kesimpulan.

\section{HASIL DAN PEMBAHASAN}

Hasil

\begin{tabular}{llr}
\multicolumn{1}{c}{ Dinas } & Pendidikan & Provinsi \\
Sulawesi & Tenggara & adalah \\
representasi & pemerintah & daerah
\end{tabular}

bidang pendidikan melakukan untuk tugasnya pada wilayah kerjanya. Tugas Dinas Pendidikan Provinsi mencakup membantu urusan pendidikan, pengawasan, penyusunan program pendidikan daerah, menyusun strategi, perumusan kebijakan pendidikan, hingga memberikan layanan umum terkait pendidikan di wilayah Sultra. Dinas pendidikan juga menjadi pembina dan pemberi izin sekolah dari taman kanak-kanak, sekolah dasar, sekolah menengah pertama, sekolah menengah atas, hingga lembaga Bimbingan Belajar (Bimbel). Sebagaimana lokus yang telah ditetapkan pada desain penelitian, maka pembahasan selanjutnya akan difokuskan pada tugas dan tanggungjawab Dinas Pendidikan Provinsi Sulawesi Tenggara pada level pendidikan Sekolah Menengah Atas (SMA) khususnya yang bersatus sebagai Sekolah Negeri, yakni SMA Negeri 1 Kendari, SMA Negeri 2 Kendari, SMA Negeri 3 Kendari, SMA Negeri 4 Kendari, SMA Negeri 5 Kendari, SMA Negeri 6 Kendari, SMA Negeri 7 Kendari, SMA Negeri 8 Kendari, SMA Negeri 9 Kendari, MAN
Negeri 1 Kendari, SMKN 1 Kendari, SMKN 2 Kendari, SMKN 3 Kendari, SMKN 4 Kendari dan SMKN 5 Kendari.

1. Persepsi Guru SMA Negeri seKota Kendari tentang Konsep Pengembangan Profesi Berkelanjutan

Menggali keberterimaan program PKB di kalangan guru, peneliti telah mewawancarai beberapa informan; guru dan kepala sekolah, terkait Persepsi Guru SMA Negeri se-Kota Kendari tentang Konsep Pengembangan Profesi Berkelanjutan. Pemaknaan petikan-petikan wawancara tersebut tersaji pada paragraph-paragraph berikut:

"Pengembangan keprofesian berkelanjutan bisa jadi kunci bagi guru untuk mengoptimalkan kesempatan pengembangan karirnya baik di saat ini maupun ke depannya. PKB semestinya akan dapat mendorong dan mendukung perubahan kualitas kami, khususnya di dalam praktikpraktik pengajaran di kelas"

"Program-program PKB yang dilaksanakan akan bermanfaat untuk: 1) meningkatkan kompetensi guru untuk mencapai standar kompetensi yang ditetapkan dalam peraturan perundangan yang berlaku; 2) memutakhirkan kompetensi untuk memenuhi kebutuhan mereka dalam perkembangan ilmu pengetahuan, teknologi dan 
seni untuk memfasilitasi proses pembelajaran peserta didik; 3) meningkatkan komitmen guru dalam melaksanakan tugas pokok dan fungsinya sebagai tenaga professional; 4) menumbuhkan rasa cinta dan bangga sebagai penyandang profesi guru; serta 5) meningkatkan citra, harkat, dan martabat profesi guru"

"Guru memperoleh kesempatan untuk melakukan pengembangan keprofesian secara berkelanjutan sehingga diharapkan dapat memperkecil jarak antara pengetahuan, keterampilan, kompetensi sosial dan kepribadian yang mereka miliki sekarang dengan apa yang menjadi tuntutan dimasa depan"

“Diharapkan, nantinya pelaksanaan pengembangan keprofesian berkelanjutan (PKB) ini akan mendorong guru untuk memelihara dan meningkatkan standar guru secara keseluruhan yang mencakup bidang-bidang berkaitan dengan pekerjaannya sebagai suatu profesi. Pada gilirannya, guru akan dapat memelihara, meningkatkan, memperluas pengetahuan, dan keterampilannya. la juga akan dapat membangun kualitas pribadi yang dibutuhkan di dalam kehidupan profesionalnya sebagai seorang guru"

2. Pengembangan Profesi Berkelanjutan Sebagai Jaminan Mutu Pendidikan di SMA Negeri se-Kota Kendari
Catatan lapangan terkait sub ini diolah kemudian disajikan dalam bentuk transkrip terstruktur sebagaimana terlihat pada kutipan-kutipan di bawah ini:

“PKB mencakup berbagai cara dan/atau pendekatan dimana guru secara berkesinambungan belajar setelah memperoleh pendidikan dan/atau pelatihan awal sebagai guru. Dengan demikian guru profesional terbentuk dengan pola belajar seumur hidup yang mengedepankan semangat hari esok harus lebih baik daripada hari ini. Hasil dari sikap profesional guru yang muncul kemudian tentunya akan bermuara akan hadirnya budaya mutu di kelas, sekolah dan dunia pendidikan"

"Tugas pokok guru adalah merencanakan, melaksanakan, dan mengevaluasi pembelajaran. Melalui program-program PKB, kompetensi pedagogik, kepribadian, sosial, dan profesional dikembangkan. Dengan demikian, kinerja guru yang sesuai dengan tuntutan akan berimplikasi pada pencapaian keberhasilan pembelajaran peserta didik. Karena menurut saya, guru yang berhasil adalah guru yang membelajarkan peserta didik sesuai dengan persyaratan pedagogik yang di dalamnya terjadi interaksi sosial yang sehat antara guru dengan peserta didik 
dan peserta didik, yang dilakukan oleh guru yang memiliki kepribadian sesuai dengan profesi pendidik, dan memiliki keahlian dalam bidang tugasnya baik dalam mentransfer sikap, pengetahuan, dan keterampilan maupun penguasaan dalam konten mata pelajarannya"

"Krisis nilai-nilai kultural yang diakibatkan teknologi berdampak pada perubahan sosial saat ini. Oleh karena itu, pendidikan memiliki peran yang sangat penting dalam menghadapi krisis nilai-nilai kultural tersebut. Pendidikan harus memiliki mutu agar dapat menghadapi permasalahan tersebut, dengan demikian guru dituntut mempunyai profesionalisme agar meningkatkan mutu pendidikan karena kehadiran guru dalam proses pembelajaran memiliki peranan yang penting, peran guru belum dapat digantikan oleh teknologi seperti radio, televise, tape recorder, internet, komputer maupun teknologi yang paling modern. Banyak unsur manusiawi yang dibutuhkan dalam proses pembelajaran yang hanya didapatkan dari guru..."

"Untuk mendapatkan guru yang profesional memang sulit, banyak hambatan di dalamnya. Dimulai dari rendahnya kompetensi guru, gajinya yang terlalu kecil, sistem perekrutan guru yang kurang mengutamakan mutu guru itu, dan kepribadian guru yang kurang berkualitas.
"Profesionalisme guru dapat ditingkatkan antara lain melalui cara sendiri-sendiri dan secara bersama-sama dengan jalan Pendidikan, Pelatihan Pembinaan teknis secara berkelanjutan, Pembentukan wadah pembinaan profesionalisme guru. Dengan semakin banyaknya guru yang profesional diharapkan pendidikan di Indonesia mengalami peningkatan dan kemajuan"

3. Masalah-Masalah yang Dihadapi oleh Para Guru SMA Negeri seKota Kendari dalam Melaksanakan Pengembangan Profesi Berkelanjutan

Berdasarkan data-data dari berbagai informan, hasil yang peneliti temukan bahwa tantangan itu antara lain adalah bagaimana guru dapat mengembangkan keprofesian berkelanjutan bagi dirinya secara optimal sedangkan kemampuan atau kompetensi guru sangat terbatas, atau fasilitasi kegiatan pengembangan diri, publikasi ilmiah, atau karya inovatif sangat sedikit. Selama ini saja, kegiatan pengembangan profesi guru masih begitu sulit dilaksanakan guru. Akibatnya, banyak guru "terhenti sementara" kenaikan pangkat dan jenjang jabatannya pada golongan ruang IV/a dengan jabatan Guru Pembina karena sulit memenuhi kewajiban mengumpulkan sekurang- 
kurangnya 12 (dua belas) angka kredit dari unsur pengembangan rofesi.

\section{Pembahasan}

1. Profesionalitas untuk Mutu sebagai Paradigma Berfikir Guru

Terpuruknya kualitas pendidikan di Indonesia ini disebabkan metode pengajaran yang tidak signifikan dan aktual dengan perkembangan yang ada (Sudarwan, 2010). Dari analisa penelitian-penelitian sebelumnya bahwa guru-guru di Indonesia tak ubahnya robot (Mulyasa, 2007). Kurang bisa berimprovisasi, berkreasi, dan inovatif. Selama ini khususnya guru terlalu anteng dininabobokan dengan sebutan "Pahlawan Tanpa Tanda Jasa" karena di lapangan banyak dijumpai sosok guru yang kurang tersentuh era globalisasi. Padahal jika merujuk Teacher \& Academy (2010), guru yang bisa mengelola dirinya sendiri akan berusaha meningkatkan kemampuan yang dimilikinya

Dalam Undang Undang Republik Indonesia Nomor 14 Tahun 2005 tentang Guru dan Dosen, pada Bab I pasal 1 disebutkan bahwa pengertian guru sebagai pendidik profesional dengan tugas utama mendidik, mengajar, membimbing, mengarahkan, melatih, menilai, dan mengevaluasi peserta didik pada pendidikan anak usia dini jalur pendidikan formal, pendidikan dasar, dan pendidikan menengah. Jika ditelaah lebih bijaksana pernyataan diatas, maka tersirat suatu tugas manajerial yang perlu dilakukan oleh seorang guru. Disebutkan bahwa tugas utama adalah mendidik, dengan pengertian bahwa seorang guru harus mampu membawa siswa pada jalur pembinaan yang tepat sasaran, yaitu dengan melakukan pembiasaan-pembiasaan yang menjadi sumber tauladan bagi perkembangan perilaku peserta didik.

Mendidik memerlukan suatu teknik yang tepat dalam upaya mempengaruhi peserta didik untuk mendapatkan bekal prilaku dan sikap yang baik. Sementara itu mengajar juga adalah suatu proses manajerial yang dilakukan guru dengan penuh pertimbangan. Proses ini memerlukan suatu perencanaan yang baik, mulai dari persiapan membuat rencana pelaksanaan pembelajaran, pemilihan materi yang tepat, pengorganisasian kelas, melakukan pengendalian berupa pemberian tes sebagai suatu alat evaluasi terhadap keberhasilan peserta didik dalam menerima pelajaran sesuai dengan pencapaian tujuan yang telah direncanakan.

Seorang guru berperan sebagai seorang manajer yang 


$\begin{aligned} & \text { melakukan } \\ & \text { pengorganisasian } \\ & \text { pengawasan }\end{aligned}$
$\begin{aligned} & \text { serta } \\ & \text { pelaksanaan } \\ & \text { pembelajaran yang } \\ & \text { ditetapkan. Sudah tentu guru } \\ & \text { sebagai sumber daya manusia }\end{aligned}$
$\begin{aligned} & \text { dalam meningkatkan kualitas } \\ & \text { pendidikan harus melakukan }\end{aligned}$
$\begin{aligned} & \text { peningkatan kompetensi diri, } \\ & \text { sehingga mampu membawa } \\ & \text { perubahan besar terhadap }\end{aligned}$
perkembangan peserta didik.

Berkaitan dengan kegiatan pembelajaran di kelas, kecenderungan yang ada saat ini secara umum guru masih menggunakan sistem yang konvensional, artinya penggunaan model atau pendekatan yang bervariasi dalam proses pembelajaran belum dapat diaplikasikan secara optimal. Hal ini dapat disebabkan oleh faktor dalam diri guru itu sendiri, keterbatasan pengetahuan, fasilitas belajar atau minat untuk meningkatkan kompetensi diri, sehingga berpengaruh terhadap rendahnya kinerja guru dalam memberikan pelayanan terhadap siswa. Jika hal ini diabaikan, maka keberhasilan dalam meningkatkan kualitas pendidikan pun akan terhambat.

Pendidikan dan pelatihan melalui program-program PKB bertujuan memupuk para guru untuk meningkatkan kualitas diri

\begin{abstract}
dalam rangka melaksanakan tugas-tugas yang berhubungan dengan proses pembelajaran. Seorang atau beberapa siswa akan berhasil dalam pembelajaraannya bilamana seorang guru telah memiliki kualitas pengajaran yang baik. Sehubungan dengan pengembangan SDM untuk peningkatan kualitas, Kartadinata (1998) mengemukakan bahwa "Pengembangan SDM berkualitas adalah proses kontekstual, sehingga pengembangan SDM melalui upaya pendidikan bukanlah sebatas menyiapkan manusia yang menguasai pengetahuan dan keterampilan yang cocok dengan dunia kerja pada saat ini, melainkan juga manusia yang mampu, mau, dan siap belajar sepanjang hayat.

Kecenderungan yang kini berlangsung adalah, bahwa seorang guru dituntut memiliki pengetahuan baru (knowledgeintensive, high techknowledgeable), yang sesuai dinamika perubahan yang tengah berlangsung. Pola yang berubah ini menuntut pengetahuan baru dan cara penanganan (manajemen) yang baru. Human capital yang mengacu kepada pengetahuan, pendidikan, latihan, keahlian, ekspertis tenaga kerja di perusahaan/sekolah kini menjadi sangat penting, dibandingkan dengan waktuwaktu lampau.
\end{abstract}




\begin{abstract}
Menegaskan dari pemikiran-pemikiran di atas, peneliti menyimpulkan bahwa guru adalah ujung tombak pendidikan. Meningkatkan profesionalisme hukumnya wajib. Kompetensi profesional mengisyaratkan luas dan dalamnya pengetahuan guru terhadap bahan yang diajarkan, kemampuan penguasaan metodologi, dan kemampuan menerapkan terus-menerus. Segala upaya guru untuk menguasai bahan pelajaran secara luas dan mendalam, menjadi syarat kompetensi guru yang profesional. Selain itu guru harus dapat menggunakan temuan-temuan bahan ajar untuk memperbaiki prosedur kerjanya. Juga pertemuan akademik dalam kegiatan ilmiah, seperti seminar, simposium, lokakarya, penelitian, karya ilmiah, dialog interaktif dan lain-lain. Proses belajar mengajar, kegiatan bimbingan pengembangan profesi sebagai penunjang proses pembelajaran.
\end{abstract}

2. Pengembangan Profesi Berkelanjutan Sebagai Jaminan Mutu Pendidikan, dan MasalahMasalah yang Dihadapi

Peraturan Pemerintah (PP) No. 74 Tahun 2008 membedakan antara pembinaan dan pengembangan kompetensi guru yang belum dan yang sudah berkualifikasi S-1 atau D-IV.
Pengembangan dan peningkatan kualifikasi akademik bagi guru yang belum memenuhi kualifikasi S-1 atau D-IV dilakukan melalui pendidikan tinggi program S-1 atau program D-IV pada perguruan tinggi yang menyelenggarakan program pendidikan tenaga kependidikan dan/atau program pendidikan non-kependidikan yang terakreditasi.

$$
\text { Peningkatan mutu }
$$

pendidikan adalah sebuah keharusan yang tidak boleh ditawar-tawar. Semua pihak terkait hendaknya memberikan perhatian dan kontribusi yang wajar dan melakukan sejumlah upaya peningkatan mutu ini. Langkah awal yang mestinya segera dilakukan adalah mengatasi sejumlah kendala yang ada. Sejumlah kendala yang timbul dalam upaya peningkatan mutu pendidikan kita antara lain belum maksimalnya perhatian dan kontribusi riil pihak-pihak terkait, khususnya para pengambil kebijakan (Jalal, 2001). Rendahnya kemampuan para pengelola pendidikan khususnya jajaran birokrasi pendidikan dalam pembuatan perencanaan, mengelola kegiatan, dan sistem pengawasannya. Juga terbatasnya anggaran pendidikan dalam APBN, APBD Provinsi, APBD kabupaten/kota, dan sumber dana lainnya sehingga mengakibatkan terbatasnya 
sarana prasarana, rendahnya kuantitas dan kualitas kegiatan peningkatan mutu setiap komponen. Belum lagi kendala yang mengkait rendahnya mutu tenaga kependidikan yang disebabkan sistem pengadaan, rekruitmen atau penempatan, pembinaan dan pengembangan karier (Hargreaves, 1994).

Persoalan ini menjadi semakin terasa, terutama pada sistem desentralisasi sebagai saat sekarang. Saat ini bukan lagi peningkatan mutu yang terjadi, tetapi persoalan silih berganti dan bertubi-tubi serta kemerosotan yang menyedihkan dan selalu menghantui. Selama ini pendidikan semakin terpuruk dan perlu diperjuangkan, termasuk memperjuangkan nasib guru. Guru sebagai komponen utama dan terpenting dalam pendidikan tetapi kondisinya jauh dari harapan. Kekurangan guru, kualitas rendah sehingga perlunya pembaharuan pendidikan dan peningkatan kualitas guru.

Berdasarkan hasil penelitian IRDA (Indonesia Rapid Decentralization Aprraisal) tahun 2006, di seluruh pelosok Indonesia permasalahan guru adalah permasalahan yang paling menonjol (Dede, 2007). Permasalahan guru dari dulu tetap berkutat pada kekurangan jumlah guru dan tidak meratanya penyebaran guru di sekolah yang ada di perkotaan dan di pedesaan atau di pedalaman. Kemudian, kualitas gurupun menjadi keprihatinan banyak pihak karena sangat banyak guru yang kurang memenuhi syarat mengajar mata pelajaran tertentu ataupun kelas tertentu yang ditugaskan kepada mereka, sehingga mereka sering menjadi kambing hitam rendahnya mutu pendidikan di tanah air.

Upaya peningkatan mutu semestinya lebih berpijak pada sistem pendidikan yang menekankan orientasi kepada proses dan hasil maka perlu dilakukan peningkatan kualifikasi dan kompetensi guru agar standar kualitas pendidikan yang diharapkan segera tercapai. Hal ini mengingatkan tentang pentingnya dilakukan pendidikan profesi keguruan yang diselenggarakan oleh perguruan tinggi yang memiliki program pengadaan tenaga kependidikan yang terakreditasi. Kebijakan ini ditempuh, mengingat bahwa pembinaan mutu tenaga pendidik bukanlah perkara yang mudah. Agar pelaksanaan pengembangan keprofesian berkelanjutan dapat mencapai tujuan yang diharapkan sesuai dengan prioritas pelaksanaan tersebut, maka pelaksanaan pengembangan keprofesian berkelanjutan harus 
didasarkan pada prinsip-prinsip sebagai berikut.

a. PKB harus menjadi bagian integral dari tugas guru sehari-hari yang berorientasi kepada keberhasilan peserta didik. Cakupan materi untuk kegiatan pengembangan keprofesian berkelanjutan harus kaya dengan materi akademik, metode pembelajaran, penelitian pendidikan terkini, teknologi dan seni, serta berbasis pada data dan hasil pekerjaan peserta didik sebagai upaya untuk meningkatkan kualitas pembelajaran.

b. Setiap guru berhak mendapat kesempatan dan wajib mengembangkan diri secara teratur, sistematis, dan berkelanjutan sesuai dengan kebutuhan pengembangan profesinya.

c. Sekolah wajib menyediakan kesempatan kepada setiap guru untuk mengikuti program PKB dengan minimal jumlah jam per tahun sesuai dengan yang ditetapkan dalam Permenneg PAN dan RB No 16 Tahun 2009. Dinas Pendidikan Kabupaten/Kota dan sekolah berhak menambah alokasi waktu jika dirasakan perlu. Untuk menghindari kemungkinan pengalokasian kesempatan pengembangan yang tidak merata, maka proses perencanaan program PKB harus dimulai dari sekolah.

d. Guru yang tidak memperlihatkan peningkatan kompetensi setelah diberi kesempatan untuk mengikuti program PKB sesuai dengan kebutuhannya, maka dimungkinkan diberikan sanksi sesuai dengan peraturan yang berlaku. Sanksi tersebut tidak berlaku bagi guru, jika sekolah tidak dapat memenuhi kebutuhan guru untuk melaksanakan program PKB.

e. Guru harus terlibat secara aktif dalam perencanaan, pelaksanaan, dan sebagai salah satu sumber informasi kegiatan monitoring dan evaluasi program PKB sehingga betul-betul terjadi perubahan pada dirinya yang berkontribusi pada peningkatan kualitas layanan pendidikan di sekolah.

f. PKB harus berkontribusi dalam mewujudkan visi, misi, dan nilai-nilai yang berlaku di sekolah dan kabupaten/kota. Oleh karena itu, kegiatan PKB harus menjadi bagian terintegrasi dari rencana pengembangan sekolah dan kabupaten/kota dalam melaksanakan peningkatan mutu pendidikan.

g. Sedapat mungkin kegiatan 
pengembangan

PKB

dilaksanakan di sekolah atau KKG/MGMP/MGBK bersamasama dengan sekolah lain, sehingga mengurangi

dampak negatif pada layanan pendidikan karena guru meninggalkan sekolah.

h. PKB harus dapat mewujudkan guru yang lebih profesional sehingga mendorong pengakuan profesi guru sebagai lapangan pekerjaan yang bermartabat dan bermakna bagi masyarakat dalam pencerdasan kehidupan bangsa.

i. PKB diharapkan dapat mendukung pengembangan karir guru yang lebih obyektif, transparan dan akuntabel (Sudarwan, 2011)

Sebagaimana

pendapat Boyt Luschdan Naylor (2001), guru merupakan unsur manusiawi yang sangat menentukan keberhasilan pendidikan. Apabila guru benar-benar memiliki tingkat profesionalitas yang tinggi dengan ditandai dimilikinya empat kompetensi yang dipersyaratkan, dapat diasumsikan bahwa pembelajaran akan berhasil dengan baik dan kualitas pembelajaran dan atau bahkan kualitas pendidikan akan dapat tercapai.

\section{KESIMPULAN}

Sebagaimana uraian-uraian pada sub pembahasan, diperoleh kesimpulan penelitian ini, yaitu:

1. Umumnya para guru memiliki kesadaran bahwa perubahan yang telah terjadi; paradigma, nilai, dan perkembangan teknologi mengharuskan mereka untuk meningkatan kemampuan, baik itu manajerial maupun pedagogik (pengajaran). Dengan demikian mereka akan mampu berdaptasi dengan situasi, khususnya mengenal dan mengaplikasikan metode-metode pengajaran yang up to date, tentunya pengembangan keprofesionalan berkelanjutan (PKB) adalah solusinya;

2. Dalam rangka menghadapi era global yang diperkirakan ketat dengan persaingan disegala bidang kehidupan, khususnya dunia kerja yang semakin kompetitif, tidak ada alternatif lain selain berupaya meningkatkan kualitas sumber daya manusia melalui upaya peningkatan mutu pendidikan di setiap jenjang pendidikan. Guna tercapainya tujuan dimaksud selain harus didukung pengembangan program seperti PKB. Melalui PKB maga guru akan: 1) meningkatkan kompetensi guru untuk mencapai standar kompetensi yang ditetapkan dalam peraturan perundangan yang berlaku; 2) 
memutakhirkan kompetensi guru untuk memenuhi kebutuhan guru dalam perkembangan ilmu pengetahuan, teknologi dan seni untuk memfasilitasi proses pembelajaran peserta didik; 3) meningkatkan komitmen guru dalam melaksanakan tugas pokok dan fungsinya sebagai tenaga professional; 4) menumbuhkan rasa cinta dan bangga sebagai penyandang profesi guru; 5) meningkatkan citra, harkat, dan martabat profesi guru di masyarakat; 6) menunjang pengembangan karir guru.

3. Beberapa kendala yang ditemukan dalam melaksanakan PKB, seperti: kompetensi guru sangat terbatas dan fasilitasi kegiatan pengembangan diri, publikasi ilmiah, atau karya inovatif sangat sedikit

\section{DAFTAR PUSTAKA}

Boyt, T. E., Lusch, R. F., dan Naylor, G. (2001). The role of professionalism in determining job satisfaction in professional services: a study of marketing researchers. Journal of Service Research, 3 (4), 321-330.

Day, C., \& Sachs, J. (2003). International Handbook on the Continuing Professional Development of Teachers. London: Open University Press.

Dede, Rosyada. (2007) Paradigma Pendidikan Demokratis. Kencana Prenada Media Group: Jakarta.
Energy, S. A., Region, B. S., Package, W., Partners, P., \& Partners, I. (2013). Concepts for the performance and recognition of professional education for young people with practical talents in Germany - Project “ Skill Alliance Energy" Introduction, 1-30.

Hargreaves, D. H (1994). The new professionalism: the synthesis of professional and institutional development, Teaching and Teacher Education, 10 (4), 423-438.

Hoyle, E. dan Wallace, M. (2007) Educational reform: an ironic perspective, Educational Management, Administration \& Leadership, 35(1) 9-25.

Jalal, Fasli. (2001) Reformasi Pendidikan Dalam Konteks Otonomi Daerah. Adicita Karya Nusa: Yogyakarta.

Kartadinata, Sunaryo. 1998. Bimbingan di Sekolah Dasar. Alfabeta: Bandung

Makka, M. A. (2003). Pengembangan keprofesian berkelanjutan dalam penilaian prestasi kerja guru, 1-7.

Mulyasa, E. (2007). Standar Kompetensi dan Sertifikasi Guru. Rosda Karya: Bandung.

Panjaitan, Y. (2005). Strategi Pelaksanaan Pengembangan keprofesian Berkelanjutan di Sekolah. Jakarta. 
Peraturan Bersama Mendiknas, Menneg PAN dan RB, Mendagri, Menkeu, dan Menag tentang Penataan dan Pemerataan Guru Pegawai Negeri Sipil, tanggal 3 Oktober 2011.

Peraturan Menteri Pemberdayaan Aparatur Negara dan Reformasi Birokrasi Nomor 16 Tahun 2009 tentang Jabatan Fungsional Guru dan Angka Kreditnya.

Peraturan Pemerintah Republik Indonesia Nomor 74 Tahun 2008 tentang Guru.

Pulungan, I. (2015). Pengembangan Keprofesian Berkelanjutan Bagi Guru Melalui Penulisan Jurnal Reflektif Mengajar. Pendidikan, 1-10.

Setiasih, O. (2010). Etika Profesi. Pendidikan, 1-31.

Sudarwan, Danim. (2011). Pengembangan Profesi Guru: Dari Induksi ke Profesional Madani. Media Perhalindo: Jakarta.

Sudarwan, Danim. (2010). Profesionalisasi dan Kode Etik Guru, Bandung. Alfabeta: Bandung.

Teacher, R., \& Academy, E. M. (2010). Professional Environment for Teacher Professional develpment. Latvia.

Undang-Undang Republik Indonesia Nomor 14 Tahun 2005 tentang Guru dan Dosen. 